\title{
Peran Aparatur Pemerintahan dalam Pelaksanaan Pembangunan Perdesaan Partisipatif di Kabupaten Bone dan Kabupaten Jeneponto Provinsi Sulawesi Selatan
}

\author{
The Role of Government Official in the Implementation \\ of Participatory Rural Development in Bone and Jeneponto \\ Regencies of South Sulawesi Province \\ Mappamiring ${ }^{1}, \mathrm{Ma}^{\prime}$ mun Sarma ${ }^{2}$, Darwis S Gani ${ }^{3}$, Pang S Asngari ${ }^{3}$ \\ ${ }^{1}$ Universitas Muhammadiyah Makassar \\ ${ }^{2}$ Fakultas Ekonomi dan Manajemen IPB \\ ${ }^{3}$ Departemen Sains Komunikasi dan Pengembangan Masyarakat, \\ Fakultas Ekologi Manusia, Institut Pertanian Bogor
}

\begin{abstract}
The arrangement of government institutions in the region, especially in the rural level is very important and urgent. The dominant factors affecting participatory rural development in Bone and Jeneponto Regencies of South Sulawesi province are the aspect of leadership, quality of human resources, awareness and sensitivity, and the level of education of the officers and public awareness. Changing the culture and access to knowledge and technology, both among the officers and the society is the key to the success of participatory rural development. There are three important aspects in the effort to create the prospect of government management and participatory rural development aspects of leadership, good governance and the aspects of sensitivity and concern for the officers. The level of stakeholders participation in all elements Bone and Jeneponto regencies of South Sulawesi Province can be categorized as medium. Achievement motivation and increased competence to the officer should be a prerequisite condition of adequate welfare, a clear career path, and the improvement of internal aspects of the system and working procedures and institutional structures of government. Community empowerment program has been running really well, but there are still weak in terms of socialization, values and traditions of feudalism, bureaucracy, as well as from the aspect of consciousness of citizens. Another phenomenon in terms of community empowerment programs is that the public is more interested in the economically productive program, so that the training programs are often considered less important and less desirable. The most prominent problems of the community empowerment program are transparancy, supervision, and socialization, and community authorities targeted purely as sub optimal.
\end{abstract}

Keywords: institutional governance, participatory, autonomy and government official

\section{PENDAHULUAN}

Manajemen pemerintahan dan pembangunan sekarang ini diperhadapkan kepada tantangan besar yaitu tuntutan otonomi daerah, reformasi dan globalisasi. Konsekuensi logis dari semua ini, adalah perlunya dilakukan penataan kelembagaan khususnya pada level pemerintahan daerah. Ujung tombak birokrasi lokal pada pemerintahan daerah adalah kelembagaan pemerintahan desa dan kecamatan. Pusat Studi Kependudukan dan Kebijakan UGM (2001:7) dalam penelitiannya menemukan bahwa reformasi birokrasi publik di Indonesia menunjukkan bahwa tingkat akuntabilitas aparatur birokrasi dalam kondisi buruk.

Isu sentralnya adalah masih diperhadapkan pada masalah-masalah umum yang sifatnya fundamental, seperti masalah kejelasan visi misi, kefiguran, kuantitas dan kualitas

\footnotetext{
${ }^{1}$ Korespondensi Penulis: 081377097724

E-mail: mappamiring@yahoo.co.id
} 
SDM aparatur, kultur, pembinaan dan pengembangan, aspek kepemimpinan, partisipasi stakeholders, good governance, kebijakan pemberdayaan masyarakat, pelayanan publik, kompetensi dan budaya kerja, motivasi, kepedulian dan kepekaan aparat, optimalisasi sumberdaya, profesionalisme birokrasi, masyarakat madani yang mandiri dan lain-lain. Keseluruhan masalah ini perlu dikaji secara mendalam guna mendapatkan gambaran yang jelas sebagai tahapan awal dalam upaya memperbaiki kinerja aparatur pemerintahan, karena sering terjadi hal-hal tersebut di atas berkaitan dengan adanya hambatan dan penyebab banyaknya program pembangunan perdesaan partisipatif yang belum berhasil secara maksimal.

Apabila masalah di atas dicermati dalam kaitannya dengan pelaksanaan program pembangunan perdesaan partisipatif di Provinsi Sulawesi Selatan, tampaknya masih merupakan hal yang sangat memprihatinkan, dalam arti keterbatasan dalam banyak hal, baik dari aspek karakteristik individual aparat, maupun dari segi profil kelembagaan. Rancangan Pembangunan Daerah 2001 - 2005, Provinsi Sulawesi Selatan memuat tentang arah kebijakan pembangunan daerah yaitu: percepatan pembangunan perdesaan dalam rangka pemberdayaan masyarakat, dilakukan dengan pendekatan profesionalisme aparat pemerintahan desa, mengembangkan kelembagaan, penguasaan teknologi tepat guna dan pemanfaatan sumberdaya alam. Sepintas dapat dikatakan bahwa wilayah perdesaan Sulawesi Selatan memiliki potensi segala macam sumberdaya yang memungkinkan seluruh sektor kehidupan tumbuh secara meyakinkan. Hanya saja fakta di lapangan menunjukkan kelemahan utama yang menonjol adalah kelemahan kelembagaan, kelemahan SDM dan hambatan pendanaan pembangunan.

Umumnya ketertinggalan masyarakat di berbagai belahan bumi berada di perdesaan, termasuk di Indonesia. Untuk mengatasi hal ini,. salah satu syarat yang harus dipenuhi adalah peningkatan kemampuan untuk berpartisipasi dalam pembangunan. Selanjutnya untuk meningkatkan partisipasi seluruh lapisan masyarakat ini diperlukan efektivitas peran kelembagaan. Hasil temuan menunjukkan bahwa, ada tiga aspek penting yang paling menentukan tingkat keberhasilan peran aparatur pemerintahan dalam pelaksanaan pembangunan perdesaan partisipatif di Kabupaten Bone dan Kabupaten Jeneponto Sulawesi Selatan yaitu: aspek kepemimpinan, derajat good governance serta aspek kepedulian dan kepekaan aparat. Memang diakui pula bahwa masih banyak hal yang perlu dibenahi secara tepat. Hal ini diperkuat oleh pendapat Wasistiono (2003) yang menyarankan agar organisasi abad 21, khususnya organisasi pemerintahan lebih mengutamakan kemampuan profesional dibandingkan kewenangan yang dimilikinya. Selain itu. Sedarmayanti dkk. (2006:) menyatakan bahwa implementasi aspek kewenangan kelembagaan, kewenangan daerah, dan sumberdaya manusia aparatur, dalam kenyataannya, otonomi daerah acapkali diinterpretasikan sebagai otonomi pemerintahan daerah dengan mengabaikan masyarakat.

Uraian singkat di atas menjadi dasar untuk merumuskan masalah sebagai berikut: (1) Faktor-faktor apa yang berhubungan dengan Manajemen pemerintahan dan pembangunan perdesaan partispatif, di Kabupaten Bone dan Kabupaten Jeneponto Provinsi Sulawesi Selatan? (2) Bagaimana pembinaan aparatur pemerintah desa dan kepemimpinan yang dapat mengintegrasikan kebijakan pembangunan Top Down dan Bottom Up, di Kabupaten Bone dan Kabupaten Jeneponto Provinsi Sulawesi Selatan? (3) Bagaimana hubungan antara faktor-faktor yang berpengaruh pada partisipasi masyarakat dalam pengelolaan pembangunan perdesaan partisipatif di Kabupaten Bone dan Kabupaten Jeneponto Provinsi Sulawesi Selatan? (4) Bagaimanakah respon masyarakat terhadap kebijakan pembangunan perdesaan partisipatif di Kabupaten Bone dan Kabupaten Jeneponto? (5) Bagaimana kualitas good governance dan strategi manajemen 
pemerintahan dan pembangunan perdesaan partisipatif di Kabupaten Bone dan Kabupaten Jeneponto Provinsi Sulawesi Selatan?

Tujuan penelitian adalah: (1) Mengidentifikasi faktor-faktor yang berhubungan dengan pengelolaan pembangunan perdesaan partisipatif, di Kabupaten Bone dan Kabupaten Jeneponto Provinsi Sulawesi Selatan; (2) menganalisis pembinaan dan pengembangan aparatur dan kepemimpinan pembangunan Perdesaan Partisipatif, di Kabupaten Bone dan Kabupaten Jeneponto Provinsi Sulawesi Selatan; (3) menganalisis tingkat keeratan hubungan antara faktor-faktor yang saling terkait dalam manajemen pemerintahan dan pembangunan perdesaan partisipatif di Kabupaten Bone dan Kabupaten Jeneponto Provinsi Sulawesi Selatan, (4) menganalisis aspek koordinasi dan komunikasi tentang penanganan permasalahan pembangunan sesuai respon masyarakat terhadap pengelolaan pembangunan perdesaan partisipatif, dan (5) merumuskan strategi manajemen pemerintahan dan pembangunan perdesaan partisipatif di Kabupaten Bone dan Kabupaten Jeneponto Provinsi Sulawesi Selatan.

\section{Metode Penelitian}

Populasi dan Sampel

Populasi penelitian adalah aparat desa dan kecamatan dengan menggunakan teknik sampling area. Jumlah populasi sebanyak 3.404 orang aparat yang terdiri dari 2.583 aparat dari Kabupaten Bone dan 821 aparat dari Kabupaten Jeneponto. Sampel sebanyak 200 responden yang diambil secara proporsional yaitu 121 orang dari Kabupaten Bone dan 79 orang dari Kabupaten Jeneponto. Kerangka sampel dipilih kombinasi probability sampling dengan non probability sampling yang dimulai dengan pengelompokkan kecamatan menjadi dua yaitu kecamatan yang bernuansa kota dan non kota, kemudian dirandom dan menghasilkan dua kecamatan untuk Kabupaten Jeneponto, dan tiga kecamatan untuk Kabupaten Bone. Selain responden ditetapkan pula tokoh informal dari warga masyarakat ditetapkan secara proporsional yaitu 40 orang; sebagai sumber data masing-masing 25 orang untuk Kabupaten Bone, 15 orang untuk Kabupaten Jeneponto. Sistematika penentuan responden dilakukan dengan menggunakan rumus Slovin (Sevilla dkk, 1993-161) yaitu:

$\mathrm{n}=\frac{\mathrm{N}}{1+\mathrm{N}(\mathrm{e})^{2}}$ Standar error yang digunakan adalah 0.15 .

Penelitian menjelaskan (explanatory research) melalui penelitian deskriptif. Penelitian asosiatif (associative research), keeratan hubungan antar variabel dalam penelitian ini dianalisis dengan mempergunakan Analisis Korelasi Spearman \& Analisis Korelasi Kanonik.

\section{Uji Validitas dan Reliabilitas}

Analisis validitas dilakukan dengan menggunakan rumus korelasi product moment. Item pernyataan atau pertanyaan dinyatakan valid jika mempunyai nilai $r$ hitung yang lebih besar dari $r$ tabel atau nilai-p < taraf nyata 5\% (Sugiyono, 1992). Hasil pengujian validitas menunjukkan terdapat 3 (tiga) item pertanyaan yang tidak valid dan sudah dikeluarkan dalam penelitian ini.

Reliabilitas instrumen/kuesioner telah diuji dengan korelasi Alpha Cronbach dan setiap peubah $\left(\mathrm{X}_{1}, \mathrm{X}_{2}, \mathrm{X}_{3}\right.$, dan $\left.\mathrm{Y}\right)$ dengan nilai koefisien dinyatakan reliabel. 


\section{Hasil Dan Pembahasan}

Pembinaan dan Pengembangan Aparatur

Dilihat dari segi usia aparatur pemerintahan desa dan kecamatan sebagai responden dalam penelitian ini dapat dikategorikan menjadi tiga yaitu usia muda antara 20-30 tahun sebanyak 43 responden atau 21.5 persen, usia menengah antara 31-45 tahun sebanyak 124 responden atau 62 persen, dan usia tua 46 tahun keatas sebanyak 33 responden atau 16.5 persen. Dari jenis kelamin didominasi oleh kaum pria sebanyak 144 responden atau 72 persen dan hampir separuh responden bermasa kerja1-5 tahun sebanyak 99 responden atau 49.5 persen. Mengenai pendidikan terakhir juga hampir separuh responden berpendidikan tinggi yaitu 94 responden atau 47 persen. Data ini menguatkan persepsi bahwa SDM aparatur perdesaan masih sangat berpotensi untuk dikembangkan. Cara pengembangan tentu dengan berbagai alternatif, namun di lapangan memang kelihatan tidak bisa dijalankan secara simultan dari berbagai segi, semuanya masih sangat terbatas. Sebagai contoh mutasi untuk promosi karir serta jaminan kesejahteraan masa depan dan fasilitas penunjang lainnya belum menjadi agenda terpenting oleh pemerintah daerah. Konsekwensi dari semua ini adalah aparat pemerintahan di tingkatan perdesaan belum sepenuhnya mampu mensinergikan strategi Bottom up dan Top down dalam pembangunan partsipatif

Pendidikan dan pelatihan aparat di perdesaan antara lain diklat tentang alokasi dana desa, pelatihan membuat peraturan desa, pelatihan membuat profil desa, APBD desa serta berbagai macam pelatihan yang dilakukan secara berkala baik tingkat daerah, maupun tingkat nasional, namun demikian kinerja aparat belum maksimal. Hasil pengamatan menunjukkan bahwa semua bentuk pembinaan itu belum dilaksanakan secara sistematis dan terencana dan terkesan dilakukan secara konvensional saja. Kurangnya monitoring atau kunjungan pimpinan daerah ketingkat perdesaan karena berbagai hal antara lain kesibukan administratif di kantor, wilayah yang terlalu luas dan terpencil, dan berbagai hal lainnya semuanya berimplikasi pada rasa tanggung jawab dan motivasi berprestasi, dan peningkatan kinerja aparat. Hal ini terlihat jelas pada Tabel 1 dan Tabel 2.

Tabel 1 Korelasi Kanonik dalam Satu Kelompok Peubah

\begin{tabular}{lcllcccc}
\hline Peubah & Koefisien & Peubah & Koefisien & Peubah & Koefisien & \multicolumn{2}{c}{ Peubah Koefisien } \\
\hline $\mathrm{X}_{22}$ & $0,7761^{* *}$ & $\mathrm{X}_{32}$ & $0,7320^{* *}$ & $\mathrm{X}_{21}$ & $0,8047^{* *}$ & $\mathrm{X}_{11}$ & $-0,5227^{* *}$ \\
$\mathrm{X}_{23}$ & $0,5916^{* *}$ & $\mathrm{X}_{33}$ & $0,7609^{* *}$ & $\mathrm{X}_{23}$ & $0,6345^{* *}$ & $\mathrm{X}_{12}$ & $0,4208^{* *}$ \\
$\mathrm{X}_{24}$ & $0,7141^{* *}$ & $\mathrm{X}_{34}$ & $0,4032^{* *}$ & $\mathrm{X}_{25}$ & $0,4350^{* *}$ & $\mathrm{X}_{13}$ & $0,4953^{* *}$ \\
$\mathrm{X}_{25}$ & $0,8264^{* *}$ & & & & & $\mathrm{X}_{14}$ & $0,6827^{* *}$ \\
& & $\mathrm{X}_{11}$ & $0,6972^{* *}$ & $\mathrm{X}_{14}$ & $-0,6268^{* *}$ & & \\
\hline
\end{tabular}

Identifikasi Faktor-Faktor yang Berhubungan dengan Pengelolaan Pembangunan Perdesaan Partisipatif

Hal-hal yang berhubungan dengan pembangunan perdesaan partisipatif terlihat jelas yang menonjol diantaranya; kebijakan pemberdayaan masyarakat dengan optimalisasi sumberdaya, kepemimpinan dengan kebijakan pemberdayaan masyarakat, motivasi berprestasi dengan kepedulian dan kepekaan, kompetensi dan budaya kerja dengan pembinaan dan pengembangan aparat, kepemimpinan dengan good governance, good governance dengan kebijakan pemberdayaan masyarakat, motivasi berprestasi dengan partisipasi stakeholders, umur dengan masa kerja, optimalisasi sumberdaya dengan masyarakat madani yang mandiri dan seterusnya dapat dilihat pada Tabel 2. Dengan demikian hipotesis kedua adalah benar dan diterima. 
Tabel 2 Korelasi antar Sub Peubah

\begin{tabular}{|c|c|c|c|c|c|c|c|c|c|c|}
\hline \multicolumn{2}{|c|}{ Peubah } & \multirow{2}{*}{$\begin{array}{c}\text { Koefisien } \\
13 \quad .427 * *\end{array}$} & \multicolumn{3}{|c|}{ Peubah Koefisien } & Peubah & Koefisien & \multicolumn{3}{|c|}{$\begin{array}{l}\text { Peubah Koefisien } \\
\end{array}$} \\
\hline $\mathrm{X}_{11}$ & $\mathrm{X}_{13}$ & & $\mathrm{X}_{33}$ & $\mathrm{X}_{34}$ & $.488 * *$ & $\mathrm{X}_{31} \mathrm{X}_{21}$ & $.244 * *$ & $\mathrm{X}_{33}$ & $\mathrm{X}_{21}$ & $-.218 * *$ \\
\hline $\mathrm{X}_{14}$ & $\mathrm{X}_{32}$ & $\ldots .249 * *$ & $\mathrm{Y}_{1}$ & $\mathrm{Y}_{2}$ & $.265^{* *}$ & $\mathrm{X}_{23}$ & $.219 * *$ & & $\mathrm{X}_{22}$ & $.355^{* *}$ \\
\hline \multirow[t]{2}{*}{$\mathrm{X}_{22}$} & $\mathrm{X}_{24}$ & $.475 * *$ & & $\mathrm{Y}_{3}$ & $.426 * *$ & $\mathrm{X}_{25}$ & $.323 * *$ & & $\mathrm{X}_{23}$ & $.447 * *$ \\
\hline & $\mathrm{X}_{25}$ & $.528 * *$ & & & $.663 * *$ & & & & $\mathrm{X}_{25}$ & $.317 * *$ \\
\hline $\mathrm{X}_{23}$ & $\mathrm{X}_{25}$ & $.412 * *$ & $\mathrm{Y}_{2}$ & $\mathrm{Y}_{3}$ & $.343 * *$ & $X_{32} X_{21}$ & $.476^{* *}$ & $\mathrm{X}_{34}$ & $\mathrm{X}_{21}$ & $-.296 * *$ \\
\hline \multirow{2}{*}{$\mathrm{X}_{24}$} & $X_{25}$ & $.471 * *$ & & $X_{22}$ & $.551 * *$ & $\mathrm{X}_{24}$ & $.280 * *$ & & $\mathrm{X}_{23}$ & $.383 * *$ \\
\hline & & & & $\mathrm{X}_{24}$ & $.415^{* *}$ & $\mathrm{X}_{22} \mathrm{Y}_{1}$ & $.409 * *$ & & $\mathrm{X}_{25}$ & $.318 * *$ \\
\hline \multirow[t]{2}{*}{$X_{33}$} & $\mathrm{Y}_{2}$ & $.488 * *$ & $\mathrm{Y}_{3}$ & $\mathrm{X}_{25}$ & $.568 * *$ & $\mathrm{X}_{23} \mathrm{Y}_{2}$ & $.321 * *$ & & & \\
\hline & $\mathrm{Y}_{3}$ & $.427 * *$ & & $X_{22}$ & $.504 * *$ & & & & & \\
\hline
\end{tabular}

** Correlation is significant at the 0.01 level (2-tailed).

\section{Analisis Tingkat Keeratan Faktor-Faktor yang Berhubungan dengan Pembangunan Perdesaan Partisipatif}

Karakteristik individu aparat memiliki keeratan hubungan dengan faktor eksternal, efektivitas kinerja birokrasi dalam upaya membangun manajemen pemerintahan dan pembangunan perdesaan partisipatif. Hal ini terlihat dari nilai koefisien korelasi kanonik $\mathrm{x}_{1}$ dengan $\mathrm{x}_{3}$ yaitu 0.471526 , demikian pula korelasi kanonik $\mathrm{x}_{2}$ dengan $\mathrm{x}_{3}$ dengan nilai koefisien korelasi 0.683310 . Korelasi Spearman juga memperlihatkan nilai koefisien korelasi $\mathrm{x}_{21}$ dengan $\mathrm{x}_{32}$ yaitu $0.476^{* *}$ (Tabel 2). Hal ini bermakna bahwa untuk memperbaiki efektivitas kinerja birokrasi, harus lebih dahulu memperbaiki karakteristik aparat, dan faktor eksternal kelembagaan. Sehingga dengan demikian hipotesis ketiga juga dapat dibuktikan kebenarannya. Hal ini jelasnya terlihat pada Tabel 3.

Tabel 3 Korelasi Antar Kelompok Peubah

\begin{tabular}{|c|c|c|c|c|c|c|c|c|c|c|}
\hline \multicolumn{2}{|c|}{ No. Koefisien } & \multirow{2}{*}{$\begin{array}{r}\text { Eigen value } \\
\operatorname{Pr}>\mathrm{F}<0.0001\end{array}$} & Sig & \multicolumn{3}{|c|}{ Peubah } & \multicolumn{2}{|c|}{ No. Koefisien } & Eigen value Sig & Peubah \\
\hline 1 & 0.837548 & & & $\mathrm{X}_{2}$ & dengan & $\mathrm{Y}$ & 7 & 0.683310 & $\operatorname{Pr}>\mathrm{f}<0.0001 \quad \alpha<0.05$ & $\mathrm{X}_{2}$ dengan $\mathrm{X}_{3}$ \\
\hline 2 & & $\operatorname{Pr}>\mathrm{F}<0.0001$ & $\alpha<0.05$ & $\mathrm{X}_{2}$ & & $\mathrm{Y}$ & 8 & & & $\mathrm{X}_{3}$ \\
\hline 3 & 0.22 & & & $\mathrm{X}$ & & Y & 9 & & $1 \alpha<0$ & engan $\mathrm{X}_{3}$ \\
\hline 4 & 0.6 & & 0.05 & $\mathrm{X}_{3}$ & & Y & 10 & & $1 \alpha<0$ & an $Y$ \\
\hline 5 & 0.4 & & 0.05 & $\mathrm{X}$ & & Y & 11 & & $29 \alpha<0.05$ & $\mathrm{X}_{2}$ \\
\hline 6 & 0.292301 & $\operatorname{Pr}>\mathrm{F}<0.0002$ & $\alpha<0.05$ & $\mathrm{X}_{3}$ & dengan & $\mathrm{Y}$ & 12 & 0.471526 & $\operatorname{Pr}>\mathrm{F}<0.0001 \quad \alpha<0.05$ & $\mathrm{X}_{1}$ dengan \\
\hline
\end{tabular}

\section{Analisis Aspek Koordinasi dan Komunikasi Tentang Penanganan Masalah Pembangunan Partisipatif}

Masalah utama implementasi pembangunan terutama pemberdayaan masyarakat adalah koordinasi antar instansi, sosialisasi program dan tingkat kesadaran dan kecerdasan masyarakat. Hal ini membuktikan perlunya meningkatkan dinamika manajemen pemerintahan dan pembangunan serta penyuluhan pada semua level birokrasi dan masyarakat. Analisis korelasi kanonik Tabel 5 menunjukkan nilai koefisien tertinggi yaitu 0.837548 mengenai korelasi antara peubah $\mathrm{X}_{2}$ dengan peubah $\mathrm{Y}$. Demikian pula korelasi antara $\mathrm{X}_{3}$ dengan $\mathrm{Y}$ dengan nilai koefisien 0.619527. Hal ini mengandung makna bahwa keeratan hubungan yang cukup tinggi antar variabel ini dapat dijadikan acuan untuk memperbaiki aspek komunikasi dan koordinasi penanganan masalah pembangunan partisipatif secara terencana dan sistematis yang selama ini dilakukan secara konvensional saja. Analisis korelasi Spearman juga menunjukkan nilai koefisien antara $\mathrm{x}_{21}$ dengan $\mathrm{x}_{33}$ yaitu $-.218^{* *}, \mathrm{x}_{21}$ dengan $\mathrm{x}_{34}$ yaitu $-.296^{* *}$. Hal ini mengandung arti bahwa pembinaan 
dan pengembangan SDM aparatur berbanding terbalik dengan motivasi berprestasi dan kepedulian dan kepekaan aparat. Dengan demikian hipotesis keempat juga terbukti kebenarannya.

\section{Respon Masyarakat Terhadap Kinerja Pemerintahan dan Pembangunan}

Sebanyak 40 tokoh informal yang merupakan representasi dari seluruh elemen masyarakat perdesaan memberi penilaian sekitar pelayanan publik, kepekaan dan kepedulian aparat, kemampuan lobi, penepatan janji aparat, transparansi dan budaya kerja dengan kategori biasa-biasa saja dan bahkan ada kecenderungan rendah.Kondisi ini membuktikan bahwa tantangan utama aparatur pemerintah perdesaan adalah pada peningkatan aspek pengetahuan, sikap dan keterampilan.

\section{Analisis Mengenai Peran Aparatur Pemerintahan dalam Pembangunan Perdesaan Partisipatif}

Hasil pengamatan di lapangan mengenai pelaksanaan pembangunan perdesaan di Kabupaten Bone dan Kabupaten Jeneponto Provinsi Sulawesi Selatan kata kuncinya terletak pada aspek kepemimpinan. Karena kepemimpinanlah yang membangun dan menata lembaga, menghimpun potensi, menggerakkan seluruh sumberdaya serta melakukan komunikasi dengan semua pihak dan terutama sekali dalam upaya mengembangkan sumberdaya manusia aparatur. Aplikasi norma-norma good governance dan norma otoda sangat tergantung pada sejauh mana komitmen kepemimpinan itu bisa dijalankan. Penilaian responden mengenai pelayanan publik yang bermutu dan implementasi program pembangunan yang efektif beraneka ragam. Namun perlu dicermati karena jawaban yang menilai aparat kurang mampu memadukan kerja administrasi perkantoran dengan tugas teknis fungsional lapangan angkanya masih tinggi yaitu 44 responden atau 22 persen dari total 200 responden. Mengubah kultur aparat dan masyarakat serta membangun struktur baru institusi pemerintahan juga masih merupakan pekerjaan rumah bagi pemerintah Kabupaten Bone dan Kabupaten Jeneponto Provinsi Sulawesi Selatan

Kepemimpinan pemerintahan dan pembangunan perdesaan partisipatif di Kabupaten Bone dan Kabupaten Jeneponto Provinsi Sulawesi Selatan, ditandai dengan dominannya aspek figur ketimbang aspek pendidikan dan pengalaman serta profesionalitas. Gaya partisipatif, direktif dan supportif fasilitatif, terobosan dan parakarsa dalam upaya pengembangan SDM aparat sangat ditentukan oleh faktor kefiguran itu. Rekrutmen politik untuk pemilihan seorang kepala desa memang sangat ditentukan oleh faktor kefiguran, sehingga tim personal aparat desa yang terbentuk pun termasuk upaya pembinaannya sangat kental bermuatan/berkaitan erat dengan aspek kefiguran apalagi belum ada peraturan daerah yang mengatur secara khusus mengenai pembinaan karir. Aspek kepemimpinan pada kelembagaan pembangunan perdesaan merupakan kekuatan aspirasional, kekuatan semangat dan kekuatan moral kreatif yang mampu mempengaruhi para anggota untuk mengubah sikap. Hal ini sejalan dengan apa yang dikemukakan oleh Kencana (Yunus 2009), bahwa pemimpin adalah orang yang mempengaruhi pihak lain melalui proses kewibawaan komunikasi sehingga orang lain tersebut bertindak sesuatu dalam mencapai tujuan tertentu. 


\section{Strategi Manajemen Pemerintahan dan Pembangunan Perdesaan Partisipatif dan Good governance}

Ujung tombak birokrasi pemerintahan adalah aparat yang berada di tingkatan perdesaan. Sebagai ujung tombak, maka harus mampu menembus hal-hal yang sulit dari berbagai macam masalah pemerintahan dan pembangunan. Dengan mengenali permasalahan yang ada sekarang ini sesuai hasil kajian yakni: kualifikasi sumberdaya aparatur perdesaan masih ada masalah dari saat rekrutmen sampai pembinaan dan pengembangannya; aspek kultur, kepemimpinan, reformasi dan revitalisasi birokrasi perdesaan merupakan tantangan pemerintahan terutama pemerintahan di daerah; sistem pemerintahan otda, good governance, era pasar bebas serta tuntutan pemberdayaan masyarakat perdesaan, memerlukan prasyarat kondisi yang luar biasa; supporting berbagai macam akses bagi aparat \& masyarakat masih ada kendala.

Masalah besar tersebut di atas, harus dihadapi dengan cara \& strategi yang tepat yaitu: membuat standar pelayanan publik yang pasti dan bermutu untuk semua langkah yang akan dilakukan dengan menjunjung tinggi nilai-nilai universal yang harus didukung oleh leadership power yang berkomitmen; khusus pada program pemberdayaan masyarakat, maka peningkatan kemampuan; peran aparat pada tiga sisi yaitu; peran teknis/koordinasi, peran sosialisasi dan peran yang sifatnya politis harus menjadi political action; dan kepemimpinan merupakan kata kunci yang pertama harus benar dan seterusnya yang lain dapat diperbaiki melalui proses pembelajaran dan penyuluhan.

Faktor-Faktor yang Berpengaruh dan Saling Berhubungan dalam Manajemen Pemerintahan dan Pembangunan Perdesaan Partisipatif

\section{Kabupaten Bone}

Uji korelasi kanonik menunjukkan nilai korelasi yang erat pada semua komponen peubah. Dengan demikian pendekatan komunikasi pembangunan dan penyuluhan dapat dilakukan pada semua komponen peubah. Namun nilai korelasi tertinggi adalah korelasi antara peubah $\mathrm{X}_{2}$ (faktor eksternal ) dengan peubah $\mathrm{Y}$ (manajemen pemerintahan dan pembangunan perdesaan partisipatif). Oleh karena itu, maka untuk lebih efesien dan lebih efektifnya pendekatan komunikasi pembangunan dan penyuluhan untuk Kabupaten Bone skala prioritasnya adalah pada peubah $\mathrm{X}_{2}$ (faktor eksternal) dan peubah $\mathrm{Y}$ (manajemen pemerintahan dan pembangunan perdesaan partisipatif), hal ini terlihat pada Tabel 4.

Tabel 4. Uji Korelasi Kanonik antar Kelompok Peubah

\begin{tabular}{clcc}
\hline Kelompok Peubah & Eigen value Sig & Keragaman & Koefisien korelasi \\
\hline $\mathrm{X}_{2}$ dengan $\mathrm{Y}$ & $\mathrm{Pr}>\mathrm{F}<.0001<0.05$ & $90.70 \%$ & 0.8442 \\
$\mathrm{X}_{3}$ dengan $\mathrm{Y}$ & $\mathrm{Pr}>\mathrm{F}<.0001<0.05$ & $66.68 \%$ & 0.7108 \\
$\mathrm{X}_{2}$ dengan $\mathrm{X}_{3}$ & $\mathrm{Pr}>\mathrm{F}<.0001<0.05$ & $66.95 \%$ & 0.7135 \\
$\mathrm{X}_{1}$ dengan $\mathrm{Y}$ & $\mathrm{Pr}>\mathrm{F}<.0001<0.05$ & $82.52 \%$ & 0.5218 \\
$\mathrm{X}_{1}$ dengan $\mathrm{X}_{2}$ & $\mathrm{Pr}>\mathrm{F}<.0021<0.05$ & $82.49 \%$ & 0.4691 \\
$\mathrm{X}_{1}$ dengan $\mathrm{X}_{3}$ & $\mathrm{Pr}>\mathrm{F}<.0001<0.05$ & $87.65 \%$ & 0.5227 \\
\hline
\end{tabular}

Keterangan : $\mathrm{X}_{1}:$ Karakteristik aparatur

$\mathrm{X}_{2}$ : Faktor eksternal kelembagaan pemerintahan

$\mathrm{X}_{3}$ : Efektivitas kinerja birokrasi

$\mathrm{Y}$ : Manajemen pemerintahan dan pembangunan perdesaan partisipatif.

Selain itu pada analisis korelasi Rank Spearman memperlihatkan korelasi dengan nilai koefisien yang merata dan sangat nyata pada semua peubah, namun yang paling 
menonjol adalah nilai koefisiem korelasi tertinggi yaitu $\mathrm{X}_{33}-\mathrm{X}_{34}\left(.578^{* *}\right)$, disusul $\mathrm{X}_{22}-$ $\mathrm{Y}_{2}\left(.570^{* *}\right)$. Artinya penyuluhan lebih efektif dilakukan pada aspek motivasi berprestasi, kepedulian dan kepekaan, kepemimpinan dan aspek birokrasi yang profesional. Hal ini dapat dilihat pada Tabel 5.

Tabel 5. Uji Korelasi Rank Spearman antar Sub Peubah

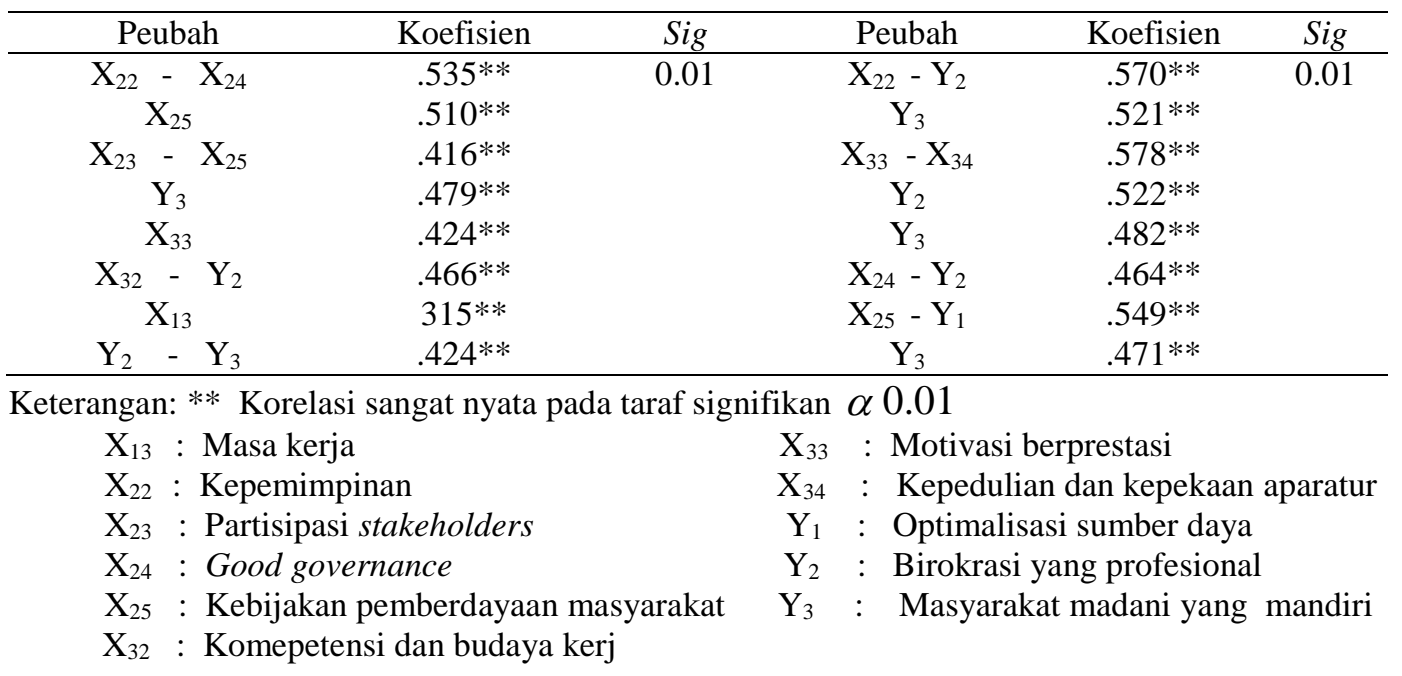

\section{Kabupaten Jeneponto}

Sama halnya dengan Kabupaten Bone, maka di Kabupaten Jeneponto juga memiliki keeratan hubungan antar kelompok peubah yang cukup kuat terutama korelasi antara peubah $\mathrm{X}_{2}$ (faktor eksternal) dengan peubah $\mathrm{Y}$ (manajemen pemerintahan dan pembangunan perdesaan partisipatif) yaitu dengan nilai koefisien 0.8821 (Tabel 6).

Hal ini berarti pelaksanaan penyuluhan lebih tepat dan lebih efisien melalui aspek faktor eksternal dan aspek manajemen pemerintahan dan pembangunan perdesaan partisipatif. Namun di sisi lain peubah karakteristik aparat tidak ditemukan adanya keeratan hubungan dengan kelompok peubah yang lain. Analisis korelasi Rank Spearman, hubungan antar peubah kelihatan merata sangat nyata pada semua peubah. Korelasi tertinggi adalah korelasi antara $X_{25}$ (kebijakan pemberdayaan masyarakat) dengan $Y_{1}$ (optimalisasi sumberdaya). Peubah yang paling banyak berkorelasi dengan peubah yang lain adalah peubah $\mathrm{X}_{25}$ (kebijakan pemberdayaan masyarakat). Hal ini berarti bahwa untuk pendekatan dan pelaksanaan penyuluhan dan pembangunan di Kabupaten Jeneponto lebih tepat dan lebih efisien melalui aspek faktor eksternal dan aspek manajemen pemerintahan dan pembangunan perdesaan partisipatif, untuk jelasnya dapat dilihat pada Tabel 6 .

Tabel 6. Uji Korelasi Kanonik antar Kelompok Peubah

\begin{tabular}{cccc}
\hline Kelompok Peubah & Eigen Value $\quad$ Sig & Keragaman & Koefisien korelasi \\
\hline $\mathrm{X}_{2}$ dengan Y & $\mathrm{Pr}>\mathrm{F}<0.0001<0.05$ & $85.76 \%$ & 0.8821 \\
$\mathrm{X}_{3}$ dengan Y & $\mathrm{Pr}>\mathrm{F}<0.0001<0.05$ & $66.69 \%$ & 0.5421 \\
$\mathrm{X}_{2}$ dengan $\mathrm{X}_{3}$ & $\mathrm{Pr}>\mathrm{F}<0.0001<0.05$ & $53.61 \%$ & 0.7481 \\
\hline
\end{tabular}

Keterangan : $\mathrm{X}_{2}$ : Faktor eksternal kelembagaan pemerintahan

$\mathrm{X}_{3}$ : Efektivitas kinerja birokrasi

$\mathrm{Y}$ : Manajemen pemerintahan dan pembangunan perdesaan partisipatif.

Uji Korelasi Kanonik antara kelompok peubah dan korelasi Rank Spearman yaitu hubungan langsung antar sub peubah secara mandiri yang agak menonjol mengenai keterkaitan beberapa peubah terlihat jelas bahwa banyak hal yang perlu menjadi dasar 
acuan dalam menata pemerintahan perdesaan partisipatif. Untuk Kabupaten Bone korelasi kanonik yang menonjol adalah korelasi kanonik peubah $\mathrm{X}_{2}$ (faktor eksternal kelembagaan) dengan peubah $\mathrm{Y}$ (manajemen pemerintahan dan pembangunan perdesaan partisipatif), peubah $\mathrm{X}_{2}$ (faktor eksternal kelembagaan) dengan $\mathrm{X}_{3}$ (efektivitas kinerja birokrasi) dan peubah $\mathrm{X}_{3}$ (efektivitas kinerja birokrasi) dengan peubah Y (manajemen pemerintahan dan pembangunan perdesaan partisipatif); sama halnya dengan korelasi kanonik pada peubah yang sama di Kabupaten Jeneponto, untuk jelasnya dapat dilihat pada Tabel 7.

Tabel 7. Uji Korelasi Rank Spearman antar Sub Peubah

\begin{tabular}{|c|c|c|c|c|c|}
\hline Peubah & Koefisien & Sig & Peubah & Koefisien & Sig \\
\hline$X_{21}-X_{31}$ & $.421 * *$ & 0.01 & $\mathrm{X}_{22}-\mathrm{X}_{23}$ & $.315^{* *}$ & 0.01 \\
\hline $\mathrm{X}_{32}$ & $.634 * *$ & & $\mathrm{X}_{24}$ & $.320 * *$ & \\
\hline $\mathrm{X}_{34}$ &.$-298 * *$ & & $X_{25}$ & $.585 * *$ & \\
\hline$X_{23}-X_{25}$ & $.421 * *$ & & $\mathrm{Y}_{1}$ & $.483 * *$ & \\
\hline $\mathrm{X}_{33}$ & $.492 * *$ & & $\mathrm{Y}_{2}$ & $.487 * *$ & \\
\hline $\mathrm{X}_{34}$ & $.338 * *$ & & $\mathrm{Y}_{3}$ & $.514 * *$. & \\
\hline $\mathrm{Y}_{2}$ & $.476 * *$ & & $X_{33}-X_{34}$ & $345 * *$ & \\
\hline $\mathrm{Y}_{3}$ & $.381 * *$ & & $\mathrm{Y}_{2}$ & $418 * *$ & \\
\hline$X_{25}-X_{24}$ & $.624 * *$ & & $\mathrm{Y}_{3}$ & $.358 * *$ & \\
\hline $\mathrm{X}_{31}$ & $.294 * *$ & & $\mathrm{X}_{24}-\mathrm{Y}_{1}$ & $.656^{* *}$ & \\
\hline $\mathrm{Y}_{1}$ & $.790 * *$ & & $\mathrm{Y}_{2}$ & $.311 * *$ & \\
\hline $\mathrm{Y}_{2}$ & $.301 * *$ & & $\mathrm{Y}_{3}$ & $.361 * *$ & \\
\hline $\mathrm{Y}_{3}$ & $678 * *$ & & $\mathrm{X}_{31}-\mathrm{Y}_{1}$ & $.374 * *$ & \\
\hline$X_{34}-Y_{3}$ & $.317 * *$ & & $X_{11}-X_{13}$ & $.564 * *$ & \\
\hline$Y_{1}-Y_{3}$ & $.569 * *$ & & $\begin{array}{c}X_{14}-X_{23} \\
X_{25}\end{array}$ & $\begin{array}{l}-.326 * * \\
-.231 *\end{array}$ & $<0.05$ \\
\hline
\end{tabular}

Keterangan: ** Korelasi sangat nyata pada taraf significant $\alpha 0.01$

* Korelasi nyata pada taraf significant $\alpha 0.05$ :

$\mathrm{X}_{11}$ : Jenis kelamin $\quad \mathrm{X}_{21}$ : Pembinaan dan pengembangan aparatur

$\mathrm{X}_{12}$ : Umur $\mathrm{X}_{22}$ : Kepemimpinan

$\mathrm{X}_{13}$ : Masa kerja $\quad \mathrm{X}_{2} 3$ : Partisipasi stakeholders

$\mathrm{X}_{14}$ : Pendidikan terakhir $\quad \mathrm{X}_{24}$ : Good governance

$\mathrm{X}_{25}$ : Kebijakan pemberdayaan masyarakat

$\mathrm{X}_{32}$ : Kompetensi dan budaya kerja $\quad \mathrm{X}_{31}$ : Pelayanan publik

$\mathrm{X}_{33}:$ Motivasi berprestasi $\quad \mathrm{X}_{34}:$ Kepedulian dan kepekaan aparatur

$\mathrm{Y}_{1}$ : Optimalisasi sumber daya $\quad \mathrm{Y}_{2}$ : Birokrasi yang profesional

$\mathrm{Y}_{3}$ : Masyarakat madani yang mandiri

Korelasi Rank Spearman untuk Kabupaten Bone yang menonjol adalah peubah $\mathrm{X}_{33}$ (motivasi berprestasi) dengan peubah $\mathrm{X}_{34}$ (kepedulian dan kepekaan aparatur) dengan koefisien korelasi $.578 * *$ Sig 0.01 . Peubah $\mathrm{X}_{22}$ (kepemimpinan) dengan peubah $\mathrm{Y}_{2}$ (birokrasi yang profesional) dengan koefisien korelasi .570** Sig 0.01 dan peubah $\mathrm{X}_{25}$ (kebijakan pemberdayaan masyarakat) dengan peubah $\mathrm{Y}_{1}$ (optimalisasi sumber daya) dengan koefisien korelasi .549** Sig 0.01. Secara keseluruhan aspek birokrasi yang profesional $\left(\mathrm{Y}_{2}\right)$, masyarakat madani yang mandiri $\left(\mathrm{Y}_{3}\right)$, dan aspek kepemimpinan $\left(\mathrm{X}_{22}\right)$ berkorelasi sangat nyata dengan banyak peubah.

Uji korelasi Rank Spearman, yang menonjol di Kabupaten Jeneponto adalah: Peubah $\mathrm{X}_{25}$ (kebijakan pemberdayaan masyarakat) dengan peubah $\mathrm{Y}_{1}$ (optimalisasi sumber daya) dengan koefisien korelasi .790** Sig 0.01. Peubah $\mathrm{X}_{25}$ (kebijakan pemberdaayaan masyarakat) dengan peubah $\mathrm{Y}_{3}$ (masyarakat madani yang mandiri) dengan koefisien korelasi .678** Sig 0.01. Peubah $\mathrm{X}_{24}$ (good governance) dengan peubah $\mathrm{Y}_{1}$ (optimalisasi sumber daya) dengan koefisien korelasi .656** Sig 0.01. Peubah $\mathrm{X}_{25}$ (kebijakan pemberdayaan masyarakat) dengan peubah $\mathrm{X}_{24}$ (good governance) dengan koefisien 
korelasi .624** Sig 0.01. Peubah $\mathrm{X}_{21}$ (pembinaan dan pengembangan aparatur) dengan peubah $\mathrm{X}_{32}$ (kompetensi dan budaya kerja) dengan koefisien korelasi .634** Sig 0.01. Peubah $\mathrm{X}_{22}$ (kepemimpinan) dengan $\mathrm{X}_{25}$ (kebijakan pemberdayaan masyarakat) dengan koefisien korelasi $.585^{*} *$ Sig 0.01. Peubah $\mathrm{Y}_{1}$ (optimalisasi sumber daya) dengan $\mathrm{Y}_{3}$ (masyarakat madani yang mandiri) dengan koefisien korelasi $.569 * *$ Sig ${ }^{{ }^{n-1}}$ Secara keseluruhan peubah yang paling banyak berkorelasi sangat nyata dengan peuoan lainnya adalah aspek kebijakan pemberdayaan masyarakat $\left(\mathrm{X}_{25}\right)$, masyarakat madani yang mandiri $\left(\mathrm{Y}_{3}\right)$, birokrasi yang profesional $\left(\mathrm{Y}_{2}\right)$, dan aspek kepemimpinan $\left(\mathrm{X}_{22}\right)$.

\section{Kesimpulan}

Faktor-faktor yang berhubungan dengan pengelolaan pembangunan perdesaan partisipatif adalah karakteristik individu aparatur, faktor eksternal kelembagaan dan efektivitas kinerja birokrasi. Keeratan hubungan tertinggi di dua kebupaten adalah korelasi faktor eksternal dengan manajemen pemerintahan dan pembangunan perdesaan partisipatif.

Pembinaan dan pengembangan aparatur pemerintahan dan pembangunan perdesaan partisipatif di Kabupaten Bone dan Kabupaten Jeneponto Provinsi Sulawesi Selatan, belum optimal. Pejabat daerah Kabupaten Bone masih kurang dalam memonitoring kinerja di tingkatan perdesaan, diklat yang dilakukan masih ada cara konvensional, rasa tanggung jawab terhadap tugas terkesan sekedar gugur kewajiban. Korelasi kanonik menunjukkan bahwa korelasinya negatif, namun korelasi Rank Spearman menunjukkan adanya korelasi yang nyata positif dengan aspek kompetensi dan budaya kerja. Di Kabupaten Jeneponto menunjukkan bahwa pembinaan dan pengembangan aparatur berkorelasi positif dan erat dengan tingkat efektivitas kinerja birokrasi.

Melihat keeratan hubungan antara faktor eksternal dengan manajemen pemerintahan dan pembangunan perdesaan partisipatif, dan faktor eksternal dengan efektivitas kinerja birokrasi, serta efektivitas kinerja birokrasi dengan manajemen pemerintahan dan pembangunan perdesaan partisipatif, mengisyaratkan bahwa, new public manajement, nilai dasar universal, serta sumberdaya dan budaya serta kearifan lokal merupakan suatu hal yang saling terkait dan tidak dapat dipisahkan satu sama lain dalam pengelolaan pemerintahan dan pembangunan perdesaan partisipatif.

Pelaksanaan fungsi dan peran aparatur di kedua kabupaten yaitu peran teknis/koordinasi, peran sosialisasi/penyuluhan dan peran yang sifatnya politis dalam penanganan masalah terutama komunikasi pembangunan perdesaan partisipatif belum maksimal didasari oleh kebutuhan, masalah dan respon masyarakat, serta kompetensi dan kepedulian aparatur.

Pelayanan publik yang bermutu, yang didukung oleh visi dan misi kepemimpinan yang berkomitmen pada kedua kabupaten yaitu Bone dan Jeneponto, masih terus berproses. Peran sosialisasi, koordinasi, dan peran politis serta penyuluhan dan komunikasi pembangunan yang dijalankan selama ini dengan mengintegrasikan nilai-nilai budaya lokal, nilai-nilai dasar universal belum maksimal, strategi human resources development dan penataan kelembagaan yang dijalankan selama ini juga terkesan masih ada cara-cara konvensional dan feodal. Kendala utamanya memang adalah aspek tur 3 tem yaitu struktur, kultur, aparatur dan sistem dan prosedur, meskipun karakter masyarakat sedikit ada perbedaan yaitu Kabupaten Bone sedikit agak individual sedangkan Kabupaten Jeneponto agak familiar. 


\section{Daftar Pustaka}

James M., Barry Z. Posner.1999. Tantangan Kepemimpinan. (Terjemahan) Batam: Interaksara

Kusmulyono, B.S. 2009. Menciptakan Kesempatan Rakyat Berusaha. Bogor: IPB Press.

Pusat Studi Kependudukan dan Kebijakan 2001. Reformasi Birokrasi Publik di Indonesia. Jogyakarta: Universitas Gajah Mada.

Sevilla, C. G., J. A. Ochave, T. G. Pursalan, B. P. Regala, dan G. G. Uriarte. 1993. Pengantar Metode Penelitian. Jakarta: UI Press

Sugiono. 1992. Metode Penelitian Administrasi. Bandung: Alfabeta

Wasistiono, S 2003 Kapita Selekta Manajemen Pemerintahan Daerah. Bandung:

Yunus, R. 2009. Aspek Kelembagaan dalam Program Pengentasan Kemiskinan di Provinsi Sulawesi Selatan. Makassar: Disertasi Program Pascasarjana Universitas Hasanuddin 